Linguistik Terapan 17 (3) (2020): 242-249.

Jurnal Linguistik Terapan Pascasarjana

Available online

http://jurnal.unimed.ac.id/2020/index.php/JLT-Unimed

\title{
CONVERSATIONAL IMPLICATURE OF ARSY AND ARSYA IN YOUTUBE CHANNEL
}

\author{
Nia Auliyah \\ Sumarsih \\ Amrin Saragih \\ English Applied Linguistics Study Program \\ Postgraduate Program-Universitas Negeri Medan
}

Diterima September 2020; Disetujui Oktober 2020; Dipublikasikan Desember 2020

\begin{abstract}
The aims of this study were to describe the kinds of Conversational Implicarture, to explain the ways of performing implicature and to describe the contex of implicature by Arsy And Arsya in Youtube channel. This research was conducted by using qualitative descriptive design. The data were the utterences of Arsy and Arsya in Youtube Channel. The data analyzes by using theory of conversational implicature.the result of this study were 1) the kinds of conversational implicatures used by Arsy and Arsya found in the text, they are Qualitative Maxim, Quantitative Maxim, Relevant Maxim, and Mannner Maxim. The analysis has found that Quantitative appeares in Arsy and Arsya YouTube Channel. (2)The process of conversational implicatures used by Arsy and Arsya in Wonderland YouTube Channel is realized through politeness strategies. (3) The reasons of the realization of conversational implicatures used by Arsy and Arsya in Wonderland YouTube Channel is realized through the system of tenor formed as [unequal/informal/positive/frequent]. It is found that there are are four. They are involved Bald on Record, Positive Politeness, Negative Politeness, and Off the Record. Off the record is the higher result found. Since she give codes to the hearer to get what her intentions, and it sometimes coded by gesture. . While in Arsya's utterances, the types of politeness implicatures found are three. They are involved Bald on Record,Positive Politeness, and Off the Record. Off the record is the higher result found. Since she give codes to the hearer to get what her intentions, and it sometimes coded by gesture.
\end{abstract}

Keywords: Implicature, Conversational Implicatuer, Politeness, Tenor, Discourse

How to Cite: Auliyah, Nia. (2020). Conversational of Arsy and Arsya in Youtube Channel. Journal Linguistik Terapan Pascasarjana Unimed. 17 (3): 242-249.

ISSN: 2407 - 7410 


\section{INTRODUCTION}

Language as a tool for communication intends to make the interaction easier. The term interaction could actually apply to a very large number of different social encounters. For example, a teacher talks to students in a classroom, and groups of friends discuss their planning are called as kinds of interactions. There are so many languages in the world that used by people in their own countries. Everyone uses language to talk each other and makes conversation in both formal and informal situation. Exactly, the most important is language has a function as the conversation tool in communication.

A communication is desired to exchange the informations. The information will be easy to understand when the speaker says clearly and informatively, not more or less. Most of the time, conversation consists of two, or more, participants. Human always produces language to express the ideas in many ways. The languages are produced with pause or silence in the spoken act is called utterances (Johnson, 2003). As a human being, communication has become social life. People need this to share and express their ideas and their feeling to other people. People sometimes converse in unreasonable way, so they may imply meaning and intention which are not stated in their actual utterances. They exchange meanings and intention. Thus, people need communication to interpret what people's mean and intend in their utterances in order to socialize with the society well.The meaning in conversation is sometimes stated explicitly and implicitly. The meaning is directly expressed in the utterances and sometimes it is not. The implicit expression provides proposition which is not expressed explicitly in the utterances. The implicit proposition of utterances is what is called by implicature. Implicature is in Pragmatics study. The conversational implicature is the single most important ideas in pragmatics (Levinson, 1983: 97). In communication, there is Cooperative principle which provides rules for conversation. It controls the participants in doing conversation, so their conversation works in cooperative and polite ways. The principle expresses four basic maxims which provide rules for how the communication should be. These rules are identified by Grice who joins the rules in a general principle called Grice's co-operative principle.

Nowadays, YouTube has become a tool of communication to make conversation to many people who can see that from the phone or laptop by connecting to the wireless. It is the largest user-driven video content provider in the world; it has become a major platform for disseminating multimedia information. YouTube show various content, such as news, games, tutorial, music, film, comedy, and also education content. People are able to create their own content and participate in all kinds of applications such as weblogs, social networking and 
online journalism. Some users create online content on a daily basis. They share their experiences and opinions about everything; from product reviews, services and baby advice to boyfriend problems, homework, make up and game tutorials. In the young ages of them, sometimes their conversation imply implicit or explisit meaning. In which their conversation also contain conversation implicature which can identified from the cooperative principle.Contrary with the cooperative principles in conversational implicature theorized by Grice, in Arsy Arsya youtue channel found conversation as follow:

In the garden,Arsy and Arsya in the garden after finishing taking guava, arsy and arsya came to her to give them the guava they had picked:

Bunda: haha.. metik jambu nih. Ini metik jambu gini?

haha.. plucking the guava. You, plucking the jambu like this?

Arsya: (No word, no expression and go on directly)

Bunda: Hahah.. (laughing)

This assumption eventually will lead to the inference of the genuine utterance. In regards with the cooperative principle, Grice (1975) explains the connection between implicatures and how it may follow or break down Gricean maxims into two ways; violating and flouting. In the text above, it can be seen Arsya utters no word. It is not violating or even flouting. It does not mean that is the destruction or the failur of the communication but precisely as a deliberate effort from the speaker to effect the certain implicature such as lying, making, funny and just kidding. Arsya does not give any response for his mother's question but go on directly. But, his mother then responses laughing as she realizes the meaning implies by his son even no words are come out or uttered by Arsya. When no words come out from the interlocuter means that the purpose of the talk exchange cannot be reached. But, in this case, his mother then smile for seeing any response from Arsya. It means that this conversation still run away and reaching the purposing as his mother merely want to see how Arsya's shaming which can be seen from steps of Arsya who suddenly go on.

In fact, Bates (1976) in Rohrig considers the study of pragmatics in child language to be very important because it occupies the interface between linguistics, cognitive and social development and enables researcher to investigate childrend's developing mental process and describe in her work that children go through three stages when acquiring pragmatics before their linguistics behavior reachs the same level of linguistics competence as the one of adults.

There are some previous studies prove that children's acquisition of implicature in diffrent age have a dirrefent ability in using implicature. For example as invedtigated by Lande (2015), in her thesis about pragmatics acquisition, she finds that four and half - year - old child has 
required implicature,that is conversational implicature even in the very simle way. The other one is a study by Pessy (2016) which focus on the speech act and implicature, she also has the same assumption as Lande's that the types of implicature acquired by a 4 year old child still in very limeted concept and just got the purpose to express what the child want.This notion reflects that there will be so many uniqueness conversational implicature. interrupt in the video uploaded in Arsy and Arsya in Wonderland YouTube channnel as seeing their young age which still included in golden age.

\section{Conversational Implicature}

A conversational implicature is not intrinsically associated with any expression. It is inferred from the use of some utterance in context. Grice's theory about "meaning" which can be divided into natural and non-natural meaning.Natural meaning refers to the meaning of thr utterance that can be generally gained by the conversational participants. While the non-natural meaning refers to intended meaning conveyed by the sepaker and must be infered by the recevier in particular context.if the participant bpth have the expectation to achieve a successfull conversation, they must cooperative with each other, and speak sincerly, sufficiently, relevantly and clearly. Tu put it another way,they must observe the co-operative principle and the maxims of quality,quantity, relation(also called relevance) and manner.if some one who participates the conversation flouts the cooperative principle and any of the maxim, it must have intended to do so. And the receiever can infer the speaker's intended meaning in particular context.

\section{A. Brown And Levinson's Theory of Politeness}

Positive face refers to the individual's desire that his wants be appreciated and approved of in social interaction. For example, when someone asks to get a pen from someone else, he can use two ways. Firstly, if he wants to apply negative face, he can say 'could you lend me a pen?'. In this case, the speaker prefers to give a freedom action to the hearer by using the word could you. Secondly, if he applies positive face, he can say 'How about letting me use your pen?'. In this case, the speaker wants be approved by using the word letting to the hearer.

\section{B. Tenor}

Tenor is the role structure. It concerns with the social relationships between those or it can be said as the social role relationships played by the interactions. For example, 
teacher/student,politician/supporter, husband/wife,friend/friend,singer/hearer etc. Tenor influences the interpersonal choices in the linguistic system, and there by it affects role the structures.

\section{YouTube}

The development of technology has included many aspects, one of them is internet. Dufi in Lestari (2017) stated that in this era, internet has an important role in human life. In additional, he also stated that several superiorities of internet are users can easily use many applications with internet browser, the users have full of control for their account and they can take the advantages from the network.

\section{METHOD}

This reserach is conducted by using qualitative research design.according to (Bodgan \&Biklen,1992:52), the design used in the research refers to the researcher plan how to proceed. Design decision is made during the study-at the end as well as the beginning. Futher, a qualitative research has five features, namely having natural setting and making the researcher as the key instrument, using descriptive words, conserning with process rather than simply with product, analyszing data inductively and having meaning as the essential concern.

Bogdan and Biklen (1992:106) defines data as the rough materials reserachers collect from the world they studying; they are particular that form the basic of analysis. Data include materials the people doing the study actively record, such as interview transcript, and participant observation fieldnotes. Data also include what other will create and the reacher finds such as diaries, photograph, official document, and newspaper articles. The instrument of collecting the data is downloader application in laptop.

To analyze the data, the researcher applied theory proposed by Miles, Huberman and Saldana (2014) namely; data condensation, data display and verification/conclusion. Data condensation stresses to the process of selecting, focusing, simplifying, abstracting and transforming. Selecting means the way to choose the best or most suitable data. In this research the researcher selects the best data based on speech functions uttered by the actors in youtube channel of Arsy and Arsya in Wonderland. Focusing means to pay attention in the particular to the suitable data. In this research the researcher only concern on suitable data for analyzing them, particularly for conversational implicature of the actors in youtube channel of Arsy and Arsya in Wonderland. 


\section{FINDINGS AND DISCUSSIONS}

The findings of the research questions about conversational implicature used by Arsy and Arsya in their YouTube Channel, the data were analyzed.

Tabel 1. Proportions of Conversational Implicatures used by Arsy and Arsya

\section{No. Maxim}

\begin{tabular}{llcc} 
& Arsy & Arsya \\
\hline 1. Qualitative & 5 & 5 \\
2. Quantitative & 26 & 5 \\
3. Relavant & 9 & 7 \\
4. Manner & 4 & 0 \\
\hline
\end{tabular}

Based on the explanation above, it can be concluded that there are different types of conversational inplicatures found in Arsy and Arsya in Wonderland YouTube Channel. In the result of Arsy, the types of conversational implicatures found are four. Quantitaive maxim is the higher result found. Quantitative Maxim focuses on the giving information as much as the second speaker in which the information not too much or too late, and in Arsy's utterances, they are more in the side of less or even no informations conveyed but sometimes, she acts to response one by gesture. While in Arsya's utterances, the types of conversational implicatures found are three. They are involved Qualitative Maxim, Quantitative Maxim, and Relevant Maxim. Irrelevant maxim is the higher presentation found. It shows that a conversation with him has not been able fully connect directly since he is still in time of playing. Thus, he cannot be focus $100 \%$ to response conversation directly.

Table 2. Realization of Conversational Implicatures Used by Arsy and Arsya in YouTube Channel

\begin{tabular}{llcccc}
\hline & & \multicolumn{2}{c}{ Arsy } & \multicolumn{2}{c}{ Arsya } \\
\cline { 3 - 6 } No. & Politeness Strategy & $\begin{array}{c}\text { Occuran } \\
\text { ce }\end{array}$ & $\begin{array}{c}\text { Percenta } \\
\text { ce }\end{array}$ & Occurance & $\begin{array}{c}\text { Percentage } \\
\text { s }\end{array}$ \\
\cline { 3 - 6 } 1. & Bald on Record & 3 & 12 & 1 & 13 \\
2. & Positive Politeness & 2 & 8 & 1 & 13 \\
3. & Negative Politeness & 4 & 16 & 0 & 0 \\
4. & Off Record & 16 & 64 & 6 & 74 \\
\hline Total & & 25 & 100 & 8 & 100 \\
\hline
\end{tabular}


The Table showed the result of the politeness strategies process used by Arsy and Arsya in Wonderland YouTube Channel. Refers to the table, it can be concluded that there are different results found between Arsy and Arsya. In the result of Arsy, the types of politeness strategies found are four. They are involved Bald on Record, Positive Politeness, Negative Politeness, and Off the Record. Off the record is the higher result found. Since she give codes to the hearer to get what her intentions, and it sometimes coded by gesture. While in Arsya's utterances, the types of politeness implicatures found are three. They are involved Bald on Record, Positive Politeness, and Off the Record. Off the record is the higher result found. Since she give codes to the hearer to get what her intentions, and it sometimes coded by gesture.

Tabel 3. The Reasons of Conversational Implicatures Used by Arsy and Arsya through Tenor

\begin{tabular}{lllcc}
\hline No. & \multicolumn{2}{c}{ System of Tenor } & Arsy & Arsya \\
\hline 1. & Status & Equal & - & - \\
& & Unequal & $\sqrt{ }$ & $\sqrt{ }$ \\
2. & \multirow{2}{*}{ Formality } & Formal & - & - \\
& & Informal & $\sqrt{ }$ & $\sqrt{ }$ \\
3. & \multirow{2}{*}{ Affect } & Positive & - & - \\
& & Negative & - & - \\
& & Neutral & $\sqrt{ }$ & $\sqrt{ }$ \\
4. & \multirow{2}{*}{ Contact } & Frequent & $\sqrt{ }$ & $\sqrt{ }$ \\
& & Infrequent & - & - \\
\hline
\end{tabular}

The table above elaborates the reasons of conversational implicatures occurred used by Arsya in their YouTube Channel. Related to the context of situation in terms of tenor, the participant that being involved in their conversation are Arsy and Arsya as the speakers and the viewer, cameraman, their mother, the nanny and the others listener or interlocutor. The status between the speakers in this occasion is unequal. The formality of the situation lied in informal environment, the affect of the conversation is positive, while the contact of conversation is frequent. Thus, the system of tenor realized in speech functions used by Arsy and Arsya formed as [unequal/informal/neutral/frequent].

\section{CONCLUSIONS}

There are four conversational implicatures used by Arsy and Arsya found in the text, The analysis has found that Quantitative appeares in Arsy and Arsya YouTube Channel as the highest result found as they give less information as they conveys the information by gesture. The process of conversational implicatures used by Arsy and Arsya in Wonderland YouTube 
Channel is realized through politeness strategies. It is found that there are are four. They are involved Bald on Record, Positive Politeness, Negative Politeness, and Off the Record. Off the record is the higher result found. Since she give codes to the hearer to get what her intentions, and it sometimes coded by gesture. While in Arsya's utterances, the types of politeness implicatures found are three. They are involved Bald on Record, Positive Politeness, and Off the Record. Off the record is the higher result found. Since she give codes to the hearer to get what her intentions, and it sometimes coded by gesture.The reasons of the realization of conversational implicatures used by Arsy and Arsya in Wonderland YouTube Channel is realized through the system of tenor formed as [unequal/informal/positive/frequent]. This point of view see the Arsy and Arsya unequal but the power in giving instructions is handed by Arsy and Arsya here to the interlocuter as they are the actors in the YouTube Channel.

\section{REFERENCES}

Barlt, M. (2018). YouTube Channels, uploads, andd views: A Statistical Analysis of The Past Tense Years.

Brasoveanu, A. (2006). Conversational Implicatures The Basis. New Jersey: Rutgers University

Cook, G. (1989). Discorse. New York: Oxford University Press

Foster, S. H. (1990). The Communicative Competence of Young Children. New York: Longman

Gaszdar,G. (1979). Pragmatics: Implicature, Presupposition and Logical Form. London : Academic Press

Geurts, B. (2010). Quantity Implicatures. Cambridge: Cambridge University Press.

Guba,E.G. (1981).Criteria for assersing the trustworthiness of of naturaistics inquires. Educational Communication and technoligy Journal 29.

Levinson, S. C. (1983).Pragmatics. Cambridge: Cambridge University Press

Miles, M. B \& Huberman, M. A. (1984). Qualitative Research Data Analysis. London:sage Publication Inc

Miller, N. E., and Dollard, J. (1941). Social Learning and Imitation. Yale University Press

Westenberg, W.(2016.) The Influence of YouTubers on Teenagers. University of Twente.

Yule, G. (1996).Pragmatic. New York: Oxford University Press.. 